\title{
Distribution of sources of household air pollution: a cross-sectional study in Cameroon
}

\author{
Miranda Baame Esong ${ }^{* *}$, André Pascal Goura², Bertrand Hugo Ngahane Mbatchou ${ }^{1,3}$, Berenice Walage ${ }^{4}$, \\ Herman Styve Yomi Simo ${ }^{4}$, Romarique Mboumo Medjou ${ }^{4}$, Martial Pianta Sonkoue ${ }^{4}$, Cyrielle Douanla Djouda ${ }^{4}$, \\ Rose Suzie Fowoh Ngnewa ${ }^{4}$, Milaine Sandra Teugueu Guiagain ${ }^{4}$, Brice-Donald Kemnang Agokeng ${ }^{2,4}$, \\ Olivia Tania Megaptche Homla ${ }^{4}$, Dan Pope ${ }^{5}$ and Jerome Ateudjieu ${ }^{2,4}$
}

\begin{abstract}
Background: Household air pollution (HAP) is a recognised risk factor for many diseases, including respiratory diseases, cardiovascular/circulatory disorders, adverse pregnancy outcomes and cataracts. Population exposure to biomass fuels, including wood, varies among countries and from one fuel source to the other. This study aimed to investigate the different sources of HAP in peri-urban and rural communities in Cameroon.

Methods: A cross-sectional survey was conducted in a representative sample of households from the Dschang Health District (DHD) region. This included 848 homes in which a range of fuels for cooking including biomass (firewood, charcoal, sawdust), kerosene and liquefied petroleum gas (LPG) were used both indoors and outdoors.

Results: Of the study households, 651 (77\%) reported exclusive use of firewood and 141 (17\%) reported using more than one source of fuel. Exclusive use of firewood was greater in rural communities (94\%) than in peri-urban communities (38\%). In peri-urban communities, use of multiple fuels including LPG, wood, sawdust and kerosene, was more common (44.75\%). A total of $25.03 \%$ of households in both peri-urban and rural communities reported using bottled gas (or liquified petroleum gas (LPG) for cooking. Motivations for choice of fuel included, affordability, availability, rapidity, and cultural factors.

Conclusion: Wood is the main cooking fuel in both peri-urban and rural communities in the Dschang Health District. Supporting households (especially those with limited resources) to adopt LPG equipment for cooking, and use in a more exclusive way is required to help reduce household air pollution.
\end{abstract}

Keywords: Indoor air pollution, Household air pollution, LPG, Fuel type, Dschang-Cameroon

\footnotetext{
* Correspondence: emirablesing@yahoo.com

'National institute of Human Research (HIHR) CLEAN-Air (Africa) Global

Health Research Group (GHRG), Mbalmayo, Cameroon

Full list of author information is available at the end of the article
}

(c) The Author(s). 2021 Open Access This article is licensed under a Creative Commons Attribution 4.0 International License, which permits use, sharing, adaptation, distribution and reproduction in any medium or format, as long as you give appropriate credit to the original author(s) and the source, provide a link to the Creative Commons licence, and indicate if changes were made. The images or other third party material in this article are included in the article's Creative Commons licence, unless indicated otherwise in a credit line to the material. If material is not included in the article's Creative Commons licence and your intended use is not permitted by statutory regulation or exceeds the permitted use, you will need to obtain permission directly from the copyright holder. To view a copy of this licence, visit http://creativecommons.org/licenses/by/4.0/ The Creative Commons Public Domain Dedication waiver (http://creativecommons.org/publicdomain/zero/1.0/) applies to the data made available in this article, unless otherwise stated in a credit line to the data. 


\section{Background}

Over 3 billion people rely on biomass fuel (BMF) as their main source of domestic energy $[1,2]$. BMF, including wood, charcoal, dung and crop residue, accounts for as much as $95 \%$ of fuel usage in lower income countries [3, 4]. Studies have shown that there is an increase in the risk of respiratory morbidity and chronic obstructive pulmonary diseases among individuals using biomass fuels $[1,5,6]$.

The World Health Statistics estimated in 2018 that acute lower respiratory infection (ALRI) is one of the leading causes of child mortality in the world, accounting for up to $15 \%$ of fatalities among children under five, almost all of them in developing countries [7]. The most recent demographic health survey for Cameroon (2018) presented $1 \%$ of children under five had symptoms of acute respiratory infections in the two weeks before the survey [8]. A recent study carried out in Bamenda regional hospital showed a prevalence of $54.7 \%$ acute respiratory infections amongst infants less than five years [9]. Household air pollution (HAP) is thought to cause about one-third of ARI cases [1]. This makes solid fuels the second most important environmental cause of disease $[6,7]$ and the fourth most important cause of overall excess mortality in developing countries [6]. In addition to impact on mortality, HAP may have long lasting effects on general health and well-being: early exposure to HAP during childhood may stifle lung development, suggesting that the cost of this pollution may continue later in life. In fact, a growing literature indicates that environmental insults at early ages can have long lasting influences on human health and productivity [10].

According to the World Health Organization (WHO) reports, deaths estimated to be related to ambient air pollution globally tripled, from 1.3 million in 2008 to 3.8 million in 2016 [11]. More than two million premature deaths each year were related to air pollution. Globally, seven million deaths were attributable to the joint effects of household and ambient air pollution in 2016 [1, 11].

In Cameroon, the industrial sector is still developing, so ambient air pollution has not reached healthdamaging levels, yet HAP is known to have caused an estimated 11,400 premature deaths in Cameroon [12]. One of the highest contributors to ambient air pollution in Cameroon is therefore BMF for cooking and space heating. To reduce this burden in the $\mathrm{LMIC}$, the World Health Organisation (WHO) recommended the adoption and scaling up of clean fuels [13, 14]. The real-time reliable knowledge about the implementation of this recommendation and the relevant needs is very still disparate in Cameroon according to areas of the country and time covered by published data meanwhile Cameroon is a multicultural country with more [15-17] than 280 different tribes and traditions.
Only few studies conducted in Northern and Southern Cameroon, have been published so far. These studies have revealed that firewood, kerosene and liquefied petroleum gas (LPG) were the main sources of cooking energy in households with close to $90 \%$ of households rely on solid fuel in rural areas [17-20]. Prices of fuels, socioeconomic status, household wealth, were listed as some of the determinants of LPG adoption in households. This study was designed to highlight the various cooking fuel types (sources of HAP) in another region of Cameroon to provide real-life information that can guide specific interventions.

\section{Methods}

This was a cross-sectional community-based study. A pretested questionnaire was administered to heads of households or representatives in randomly selected urban and rural households in the Dschang Health District (DHD) in Cameroon from March to July 2018 to estimate the distribution of sources of household air pollution and characteristics. The DHD is a cosmopolitan district with an estimated population of 221,037 inhabitants in 2018. This district was chosen because of the diversity and big size of its population and ability to compare rural and urban household characteristics. It is made up of 22 Health Areas (HA) classified into urban and rural.

The minimum sample size was estimated assuming a proportion of $50 \%$ of the population used biomass (since the prevalence of HAP was unknown, to the best of our knowledge), a 95\% confidence level, a 5\% relative precision, a cluster effect of 2 and a $20 \%$ nonresponse rate.

Multistage stratified random sampling was performed among $22 \mathrm{HA}$ to select $11 \mathrm{HA}$ with equal representation of urban (2/4) and rural (9/18) health areas. Within selected health areas, villages/ quarters were selected by simple randomisation from the list of clusters obtained from the National Institute of Statistics. The sample required from each health area was calculated with respect to their representativity in the general population (2018). In villages/quarters, a guide was solicited from the local traditional authorities and the central spot was identified. On the left/right side of the street, one household was targeted after one was skipped till the end of the street. The process was repeated until the expected sample size of households for the village was reached.

A household was defined in this study as one or more persons living together, sharing the same roof and kitchen. All unoccupied buildings were 
Table 1 Distribution of households reached in targeted health areas with population in 2018 by cluster and setting

\begin{tabular}{|c|c|c|c|c|}
\hline $\begin{array}{l}\text { Targeted Health Areas of the } \\
\text { study }\end{array}$ & $\begin{array}{l}\text { Urban or } \\
\text { Rural }\end{array}$ & $\begin{array}{l}\text { Population size in } 2018 \\
\text { (inhabitants) }\end{array}$ & $\begin{array}{l}\text { Clusters (Reached/ } \\
\text { Expected) }\end{array}$ & $\begin{array}{l}\text { Households } \\
\text { reached }\end{array}$ \\
\hline Fiala-Foreke (1) & Urban & 34,760 & $20 / 20$ & 197 \\
\hline Balevouni (2) & Rural & 1856 & $1 / 1$ & 12 \\
\hline Nkeuli (3) & Rural & 2691 & $2 / 2$ & 19 \\
\hline Fotetsa (4) & Rural & 5128 & $3 / 3$ & 28 \\
\hline Maka (5) & Urban & 10,804 & $6 / 6$ & 60 \\
\hline Fonakeukeu (6) & Rural & 5149 & $3 / 3$ & 30 \\
\hline Lepoh (7) & Rural & 10,472 & $6 / 6$ & 60 \\
\hline Ndoh-Djuttitsa (8) & Rural & 13,663 & $9 / 9$ & 93 \\
\hline Baleveng (9) & Rural & 20,658 & $12 / 12$ & 118 \\
\hline Doumbouo (10) & Rural & 16,908 & $10 / 10$ & 99 \\
\hline Mbeng (11) & Rural & 20,508 & $13 / 13$ & 132 \\
\hline TOTAL & I & 142,597 & $85 / 85$ & 848 \\
\hline
\end{tabular}

excluded and replaced by the one immediately next to it.

\section{Data collection and management}

In targeted households, data was collected from head of households or representative after verbal/signed consent was obtained. Data was collected using a structured questionnaire administered in face to face interview by a trained surveyor. The questionnaire developed by the study team was pretested in households of one of the
DHD health areas which was not selected and included in the study. For each household, data was collected on socio demographic information and characteristics of indoor sources of air pollution including fuels used for cooking. Primary cooking fuel was defined as the fuel used mainly by a household for cooking [4]. Secondary cooking fuel was defined as the fuel used as a backup for fuel-specific cooking activities by a household.

Resulting forms were verified daily to assess quality and completion. The resulting database was cleaned and

Table 2 Socio-demographic presentation of the study sample

\begin{tabular}{|c|c|c|c|c|c|}
\hline Characteristics & Modalities & Urban & Rural & Total & $P$ value \\
\hline Reached households $(n)$ & / & 257 & 591 & 848 & \\
\hline Response rate (\%) & / & 99.2 & 100 & 99.8 & \\
\hline \multirow[t]{2}{*}{ Gender $[n(\%)]$} & Female & $187(72.8)$ & $481(81.4)$ & $668(78.8)$ & $\underline{0.005}$ \\
\hline & Male & $70(27.2)$ & $110(18.6)$ & $180(21.2)$ & \\
\hline Age of respondent $(\mu \pm S D)$ & / & $31.1 \pm 12.9$ & $41.5 \pm 20.0$ & $38.3 \pm 18.8$ & $\leq 0.0005$ \\
\hline Average household size $(\mu \pm S D)$ & / & $5.4 \pm 2.8$ & $4.7 \pm 2.4$ & $4.9 \pm 2.6$ & $\leq 0.0005$ \\
\hline \multirow[t]{4}{*}{ Mother's level of education [ $n(\%)]$} & No school & $13(5.5)$ & $96(16.3)$ & $109(13.2)$ & $\leq 0.0005$ \\
\hline & Primary & $63(26.7)$ & $307(52.0)$ & $370(44.8)$ & \\
\hline & Secondary & $112(47.5)$ & $181(30.7)$ & $293(35.5)$ & \\
\hline & Higher & $48(20.3)$ & $6(1.0)$ & $54(6.5)$ & \\
\hline \multirow[t]{4}{*}{ Father's level of education [n (\%)] } & No school & $10(4.4)$ & $103(18.0)$ & $113(14.1)$ & $\leq 0.0005$ \\
\hline & Primary & $70(30.6)$ & $275(48.2)$ & $345(43.1)$ & \\
\hline & Secondary & $92(40.2)$ & $168(29.4)$ & $181(32.5)$ & \\
\hline & Higher & $57(24.9)$ & $25(4.4)$ & $6(10.2)$ & \\
\hline \multirow[t]{5}{*}{ Mother's occupation [n (\%)] } & Housewife & $47(20.0)$ & $29(4.9)$ & $76(9.3)$ & $\leq 0.0005$ \\
\hline & Farming & $55(23.4)$ & $452(77.4)$ & $507(61.9)$ & \\
\hline & Self-employment & $69(29.4)$ & $73(12.5)$ & $142(17.3)$ & \\
\hline & Civil servant & $29(12.3)$ & $23(3.9)$ & $52(6.3)$ & \\
\hline & Student & 35 (14.9) & $7(1.2)$ & $42(5.1)$ & \\
\hline
\end{tabular}


Table 3 Distribution of cooking fuel types in the households of the Dschang Health District

\begin{tabular}{lllll}
\hline Cooking instruments & Urban $[\boldsymbol{n}(\%)]$ & Rural $[\boldsymbol{n}(\%)]$ & Total $[\boldsymbol{n}(\%)]$ & $\boldsymbol{P}$ value \\
\hline Firewood only* & $97(37.7)$ & $533(74.3)$ & $630(74.3)$ & $\leq 0.0005$ \\
Firewood & $191(74.3)$ & $577(97.8)$ & $768(90.6)$ & $\leq 0.0005$ \\
Gas only* & $38(14.8)$ & $10(1.7)$ & $48(5.7)$ & $\leq .0005$ \\
Gas & $143(55.6)$ & $69(11.7)$ & $212(25.0)$ & $\leq 0.0005$ \\
Kerosene stove & $14(5.5)$ & $12(2.0)$ & $26(3.1)$ & 0.008 \\
Charcoal & $33(12.8)$ & $6(1.0)$ & $39(4.6)$ & $\leq 0.0005$ \\
Saw dust & $26(10.1)$ & $6(1.0)$ & $32(3.0)$ & $\leq .0005$ \\
\hline
\end{tabular}

* Exclusive use of the fuel type

analyzed by a statistician using Epi info version 7.2.2 software. Main analysis performed were proportions with a 95\% confidence interval and tables were designed using MS-Excel 2013.

\section{Ethical considerations}

The proposal of this study was submitted and evaluated by the National Ethics Committee of Human Health Research of Cameroon and approval was given with the reference number 1030. Prior to this evaluation, authorization was obtained in a signed document from local health authorities of the DHD. For each village/ quarter, authorization was obtained from local traditional authorities. Data was collected from consenting households.

\section{Results}

As detailed in Table 1, 11 health areas were selected $2 / 4$ in urban and $9 / 18$ in rural setting - leading to a final

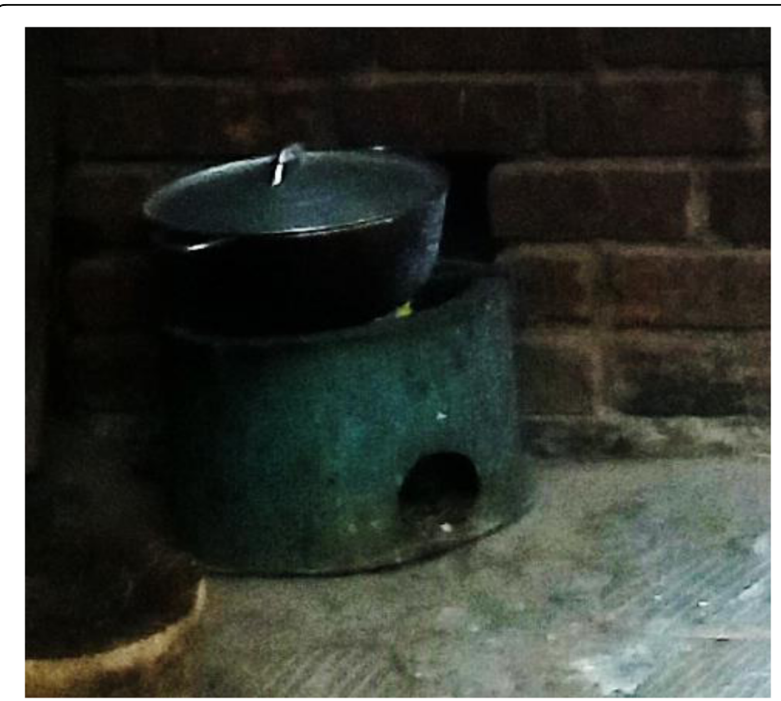

Fig. 1 Picture of a charcoal fuel sources, taken in a household enrolled in the study sample of 848 households (98\% response rate) within 85 villages/quarters. The study sample included 257 urban and 591 rural household. Approximately $80 \%$ of respondents were females. The mean age of respondents was 38 (SD: 18.8) years, median age was 33 [range: 15-97] years. Average household size was 5 (Table 2). Nearly $15 \%$ of female respondents had never been to school and $60 \%$ of female participants reported peasant farming as their main occupation.

\section{Main sources of household air pollution in the DHD}

From this study, 90\% of households used firewood and about $75 \%$ (630 households) of them exclusively used wood. Almost all households (98\%) used wood to meet at least some of their cooking needs in rural HAs. Our results also reveal that $25 \%$ household have access to domestic gas for cooking, with a higher proportion in urban areas (55.6\%) (Table 3). Figures 1 \& 2 show the pictures of a charcoal and firewood fuel source, snapped

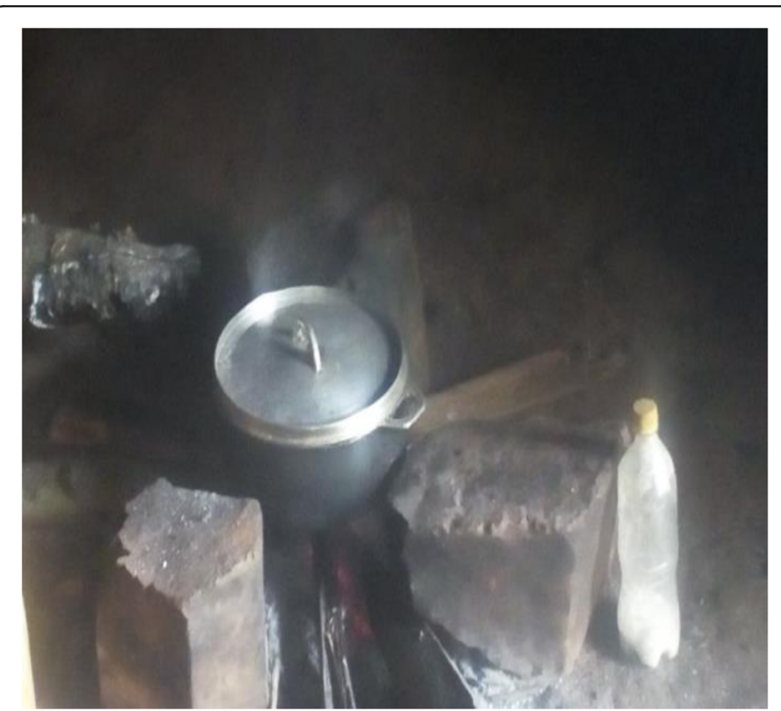

Fig. 2 Picture of a firewood fuel source at household level. This picture was snapped in a household enrolled in the study 
Table 4 Distribution of multiple cooking fuel type utilization in the Dschang Health District

\begin{tabular}{|c|c|c|c|c|}
\hline Number of cooking fuel sources & Urban $[n(\%)]$ & Rural $[n(\%)]$ & Total $[n(\%)]$ & $P$ value \\
\hline More than one source of cooking fuel & $114(44.4)$ & $67(11.3)$ & $181(21.3)$ & $\leq 0.0005$ \\
\hline More than two sources of cooking fuel & $29(11.3)$ & $4(0.7)$ & $33(3.9)$ & $\leq 0.0005$ \\
\hline More than three sources of cooking fuel & $8(3.1)$ & $0(0.0)$ & $8(0.9)$ & $<0.0005$ \\
\hline
\end{tabular}

in two separate households enrolled in the study. $P$-value less than 0.0005 as presented in Table 3 means the difference in proportion between urban and rural settings is statistically significant. It is important to note that no one was found to use an electric cooker or a micro wave.

Among the interviewed households, approximately $75 \%$ use more than one cooking fuel type (Table 4).

\section{Factors influencing the choice of cooking fuel type}

Nearly $60 \%$ of households choose their fuel type based on affordability and only $18 \%$ based on availability (Tables 5 and 6). Availability meant the presence of the fuel type in the surroundings of the household.

\section{Burden of exposure to sources household of air pollution}

Figure 3 shows the frequency of both lone and multiple cooks in households. In 9 out of 10 households interviewed, women were reported to be the main cook. Children were involved in cooking in more than $60 \%$ of the households and men in only $7 \%$ of the households. It is to be emphasised that only the mothers in 270 (31.84\%) and the children in $42(4.95 \%)$ were in charge of the cooking.

Food was cooked an average of one time $(1.3 \pm 0.5)$ per day in study households, with no variation between rural and urban areas. More than $3 / 4$ of households have been using their primary fuel type for more than five years (Table 7). Firewood has been used for the entire lifespan in almost all the households.

Table 5 Distribution of reasons influencing choice of cooking fuel type in the Dschang Health District

\begin{tabular}{lllll}
\hline Reasons & Urban [n (\%)] & Rural [n (\%)] & Total [n (\%)] & $P$ value \\
\hline Affordability & $130(50.6)$ & $375(63.4)$ & $505(59.5)$ & $\leq 0.0005$ \\
Availability & $27(10.5)$ & $122(20.6)$ & $149(17.6)$ & \\
Rapidity & $44(17.1)$ & $31(5.2)$ & $75(8.8)$ & \\
Culture & $8(3.1)$ & $40(6.8)$ & $48(5.7)$ & \\
Easy to use & $33(12.8)$ & $17(2.9)$ & $50(5.9)$ & \\
Cleanliness & $10(3.9)$ & $5(0.8)$ & $15(1.8)$ & \\
Other reason & $5(1.9)$ & $1(0.2)$ & $6(0.7)$ & \\
\hline
\end{tabular}

\section{Discussion}

This study describes the different primary fuel types used by households in a highly populated health unit in Cameroon. These fuel types are the main sources of air pollution in households, and consequently, of many related diseases prevalent in Sub Saharan Africa. The distribution of the use of one or multiple fuel types, including the various combinations is necessary to give a real-life picture of the needs and determinants influencing the implementation of the global recommendation of adopting clean fuels for the reduction of air pollution in this area of Cameroon, in both rural and urban settings.

\section{Sources of household air pollution}

Results of this study reveal that firewood is the main biomass fuel type used in the Dschang Health District $(90 \%)$ with a significant difference between the rural and urban settings. Other fuel types including domestic gas, kerosene, charcoal and sawdust, are also used in households with slight disparities between rural and urban, yet $75 \%$ of the population strictly rely on firewood for cooking. Approximately $75 \%$ of households of the DHD use more than one source of fuel however, this proportion was very low in the rural settings $(11.3 \%)$. The results of this study are in accordance with the studies conducted so far in other areas of Cameroon, showing that households mostly rely on solid fuel (especially firewood) for cooking with a higher proportion in rural areas [17-20]. Another published study conducted in another city of the same region (Bafoussam, which is the regional capital) had much lower reported solid fuel use (48\%); the difference can be explained by the fact that it was conducted exclusively in an urban area with a smaller sample of household [21]. As also found in the same studies, other fuel types including domestic gas, kerosene, charcoal and sawdust are used but household access is still very limited (less than 5\% at community level) for cooking; electricity is strictly used for no other purposes other than lighting. The use of clean fuels is still limited in both rural and urban areas of the DHD and therefore, the risk of developing HAP related diseases is 
Table 6 Distribution of main reasons of choice per main cooking fuel types in the Dschang Health District

\begin{tabular}{|c|c|c|c|c|c|c|c|c|c|c|c|c|}
\hline \multirow[b]{2}{*}{ Reasons } & \multicolumn{4}{|c|}{ Firewood [n (\%)] } & \multicolumn{4}{|c|}{ Gas [n (\%)] } & \multicolumn{4}{|c|}{ Charcoal [n (\%)] } \\
\hline & $U$ & $\mathbf{R}$ & $T$ & $P$ value & $\mathrm{U}$ & $R$ & $T$ & $P$ value & $\mathrm{U}$ & $\mathbf{R}$ & $T$ & $P$ value \\
\hline Affordability & $118(61.8)$ & $373(64.5)$ & $491(63.9)$ & $\leq 0.0005$ & $52(36.4)$ & $37(53.6)$ & $89(42.0)$ & 0.08 & $16(48.5)$ & $4(66.7)$ & $20(51.3)$ & 0.05 \\
\hline Culture & $8(4.2)$ & $40(6.9)$ & $48(6.2)$ & & $4(2.8)$ & $3(4.4)$ & $7(3.3)$ & & $0(0.0)$ & $0(0.0)$ & $0(0.0)$ & \\
\hline Rapidity & $22(11.5)$ & $28(4.8)$ & $50(6.5)$ & & $36(25.2)$ & $9(13.0)$ & $45(21.2)$ & & $5(15.2)$ & $0(0.0)$ & $5(12.8)$ & \\
\hline Cleanliness & $5(2.6)$ & $3(0.5)$ & $8(1.0)$ & & $8(5.6)$ & $2(2.9)$ & $10(4.7)$ & & $4(12.1)$ & $0(0.0)$ & $4(10.3)$ & \\
\hline Easy to use & $12(6.3)$ & $13(2.2)$ & $25(3.2)$ & & $25(17.5)$ & $6(8.7)$ & $31(14.6)$ & & $7(21.2)$ & $0(0.0)$ & $7(17.9)$ & \\
\hline Availability & $24(12.6)$ & $120(20.8)$ & $144(18.7)$ & & $15(10.5)$ & $11(15.9)$ & $26(12.3)$ & & $1(3.0)$ & $2(33.3)$ & $3(7.7)$ & \\
\hline Other reason & $2(1.1)$ & $1(0.2)$ & $3(0.4)$ & & $3(2.1)$ & $1(1.4)$ & $4(1.9)$ & & $0(0.0)$ & $0(0.0)$ & $0(0.0)$ & \\
\hline
\end{tabular}

$U$ Urban, $R$ Rural, $T$ Total

permanently high for the people living in this area. Interventions targeting increasing population access to non-solid fuels (clean fuels) with consideration of rural and urban disparities should also be urgently implemented in this health district.

\section{Factors influencing the choice of fuel type}

Interviewed head of households or representatives cited a number of factors influencing the choice of their cooking fuel type; affordability (59.5\%) and availability (17.6\%) were the main reasons. Other concerns were speed of cooking, ease of use, tradition, cleanliness and health and safety. This is in agreement with other studies carried out in different low-income areas of the world and other regions of Cameroon [17-20]. The population preferred to use wood traditionally since they found it easy to get, that is either from their farms or comparatively cheaper (pay as you go) with respect to other sources of fuel such as gas since getting gas entails disbursing large amounts of money for an initial kit (gas burner, cylinder and accessories). Given the main reasons of choice of cooking fuels presented in this study, we believe that projects aiming to support households financial

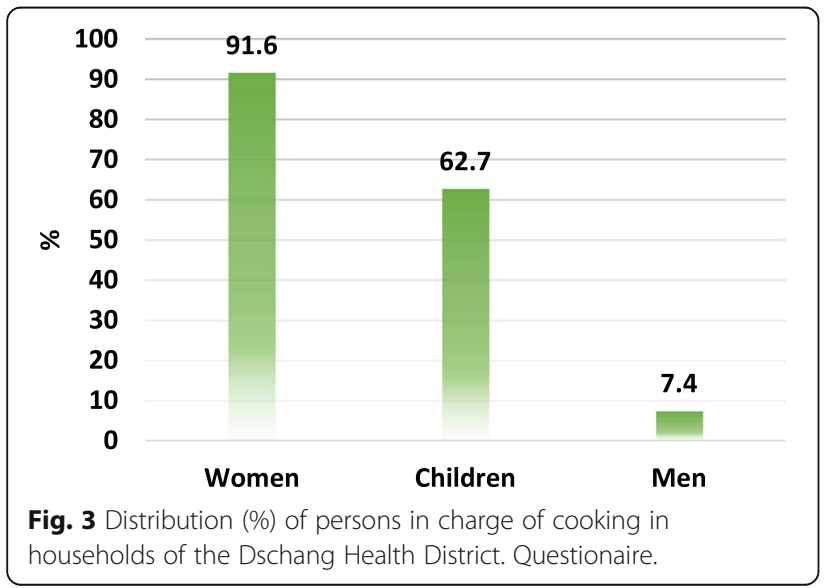

access to LPG fuels can increase reduce the proportion of households relying on unclean fuels.

\section{To whom the burden of exposure to sources household of air pollution}

This research study has shown that mothers and children were mostly those under this heavy load of HAP. Because of their customary involvement in cooking, especially women's and children exposure is much higher than men's as found in other studies [3, 22-25]. Some children pay the prize of either been carried on the back during cooking hours or laid to sleep on kitchen beds during the cooking process.

These women and children have been exposed to IAP almost all their lives, since almost every $\mathrm{HH}$ (92.7 for Urban vs 98.4 for Rural) has been using firewood as their cooking fuel for more than 5 years and only $24 \%$ of households have used LPG as their source of cooking fuel for the same duration. This is confirmed by data from the National Demographic Health Survey which presented a prevalence of $28.1 \%$ of acute respiratory infections in children under five in 2014 [26]. Showing that the continuous exposure of the population to HAP is not leaving their health indifferent. As such, studies to evaluate their effective degree of HAP exposure and interventions to aiding the population to switch from solid fuels to cleaner sources of fuel is imperative.

\section{Strength and limitations}

This study was not without limit which however did not alter the credibility of the data presented. The principal limitation is information bias due to the fact that data collection procedures relied solely on the declaration of participants (heads of households or their representatives). 
Table 7 Duration of usage of principal fuel type

\begin{tabular}{|c|c|c|c|c|c|c|c|c|}
\hline \multirow{2}{*}{$\begin{array}{l}\text { Fuel } \\
\text { types }\end{array}$} & \multirow[t]{2}{*}{ Duration } & \multicolumn{2}{|l|}{ Urban } & \multicolumn{2}{|l|}{ Rural } & \multicolumn{2}{|l|}{ Total } & \multirow[t]{2}{*}{$P$ value } \\
\hline & & $n(\%)$ & $(95 \% \mathrm{Cl})$ & $n(\%)$ & $(95 \% \mathrm{Cl})$ & $n(\%)$ & $(95 \% \mathrm{Cl})$ & \\
\hline \multirow[t]{2}{*}{ Firewood } & $<=5 \mathrm{yrs}$ & $14(7.3)$ & $(4.1-12.0)$ & $9(1.6)$ & $(0.8-2.9)$ & $23(3.0)$ & $(2.0-4.5)$ & $\leq 0.0005$ \\
\hline & $>5 \mathrm{yrs}$ & $177(92.7)$ & $(88.0-95.9)$ & $569(98.4)$ & $(97.1-99.2)$ & 746 (97.0) & $(95.5-98.0)$ & \\
\hline \multirow[t]{2}{*}{ Gas } & $<=5 \mathrm{yrs}$ & $40(28.0)$ & $(20.8-36.1)$ & $10(14.5)$ & $(7.2-25.0)$ & $50(23.6)$ & (18.0-29.9) & $\underline{0.03}$ \\
\hline & $>5 y r s$ & $103(72.0)$ & $(63.9-79.1)$ & $59(85.5)$ & $(75.0-92.8)$ & $162(76.4)$ & $(70.1-82.0)$ & \\
\hline \multirow[t]{2}{*}{ Charcoal } & $<=5 \mathrm{yrs}$ & $6(18.2)$ & $(7.0-35.5)$ & $1(16.7)$ & $(0.4-64.1)$ & $7(17.5)$ & $(7.5-33.5)$ & 0.93 \\
\hline & $>5 \mathrm{yrs}$ & 27 (81.8) & $(64.5-93.0)$ & $5(83.3)$ & (35.9-99.6) & $32(82.0)$ & $(66.5-92.5)$ & \\
\hline \multirow[t]{2}{*}{ Kerosene } & $<=5 \mathrm{yrs}$ & $4(28.6)$ & $(8.4-58.1)$ & $1(8.3)$ & $(0.2-38.5)$ & $5(19.2)$ & $(6.5-39.3)$ & 0.19 \\
\hline & $>5 y r s$ & $10(71.4)$ & (41.9-91.6) & $11(91.7)$ & $(61.5-99.8)$ & $21(80.8)$ & $(60.6-93.4)$ & \\
\hline \multirow[t]{2}{*}{ Saw dust } & $<=5 \mathrm{yrs}$ & $4(15.4)$ & $(4.4-34.9)$ & $1(16.7)$ & $(0.4-64.1)$ & $5(15.6)$ & $(5.3-32.8)$ & 0.94 \\
\hline & $>5 \mathrm{yrs}$ & 22 (84.6) & $(65.1-95.6)$ & $5(83.3)$ & (35.9-99.6) & $27(84.4)$ & $(67.2-94.7)$ & \\
\hline
\end{tabular}

\section{Conclusion}

This study brings out the use of wood for cooking as the main source of HAP for both urban and rural health areas of the Dschang Health District, Western Cameroon. The exclusive use of wood was greater in rural communities than in peri-urban communities. The choice of fuel type was mainly price and availability related. As such, interventions to help households (especially those who are resource poor) to adopt LPG equipment for cooking, and use in a more exclusive way is required. Education could help address some of the concerns over the use of LPG. More studies should be carried out on HAP in other regions of Cameroon so that a true picture of the nation's state as concerns household air pollution be exposed, to bring out the relationship or association between indoor air pollution and respiratory related diseases and other health impacts, and to measure the degree of exposure to indoor air pollution.

\section{Abbreviations}

DHD: Dschang Health District; HA: Health Area; HH: Household; HD: Health District; IAP: Indoor Air Pollution; ARI: Acute Respiratory Infection

\section{Acknowledgements}

The authors hereby thank all:

The health and traditional authorities for giving them access into their communities;

Interviewees for their patience and collaboration during the data collection.

\section{Authors' contributions}

Conception and design of the study and data collection tools: MBE, APG and JA; Data collection and entry: MBE, WB, HSYS, BDKA, OTMH, RMM, CDD, RSFN, MSTG; Database cleaning and data analysis: APG; Drafting and editing the manuscript: EMB, APG, DP, BHNM, MPS. All authors red and approved the final manuscript.

\section{Funding}

The study was funded by the principal investigator, named Baame Miranda Esong, who was involved in the design of the study, collection, analysis, and interpretation of data and in writing the manuscript.

\section{Availability of data and material}

The database of this study is not available online but can be shared on request from the authors.

\section{Ethics approval and consent to participate}

The proposal of this study was submitted and evaluated by the National Ethics Committee of Human Health Research of Cameroon (reference number 1030). Prior to this evaluation, authorization was obtained from local health authorities of the DHD and for each village/quarter, authorization was obtained from local traditional authorities. Data was collected from consenting households and personal data are not published in this study. Verbal informed consent was obtained from head of households as approved by the National Ethics Committee.

\section{Consent for publication}

Not applicable.

\section{Competing interests}

The authors declare that they have no competing interests.

\section{Author details}

${ }^{1}$ National institute of Human Research (HIHR) CLEAN-Air (Africa) Global Health Research Group (GHRG), Mbalmayo, Cameroon. ${ }^{2}$ Meilleur Accès aux Soins de Santé (M.A. SANTE), Yaoundé, Cameroon. ${ }^{3}$ Douala General Hospital, Douala, Cameroon. ${ }^{4}$ Faculty of Medicine and Pharmaceutical Sciences, Department of Public Health, University of Dschang, Dschang, Cameroon. ${ }^{5}$ Department of Public Health and Policy, University of Liverpool, Liverpool, UK.

Received: 6 April 2020 Accepted: 27 January 2021

Published online: 08 February 2021

\section{References}

1. Fullerton DG, Semple S, Kalambo F, Suseno A, Malamba R, Henderson G, et al. Biomass fuel use and indoor air pollution in homes in Malawi. Occup Environ Med. 2009 Nov;66(11):777-83.

2. Langbein J. Firewood, smoke and respiratory diseases in developing countries-The neglected role of outdoor cooking. PLoS One [Internet]. 201728 [cited 2019 May 8];12(6). Available from: https://www.ncbi.nlm.nih. gov/pmc/articles/PMC5489158/

3. Agrawal S, Yamamoto S. Effect of indoor air pollution from biomass and solid fuel combustion on symptoms of preeclampsia/eclampsia in Indian women. Indoor Air. 2015;25(3):341-52.

4. Manish A. Desai KRS. Indoor smoke from solid fuels assessing the environmental burden of disease at national and local levels. World Health Organization Protection of the Human Environment Geneva 2004; 2004. Available from: https://www.who.int/quantifying_ehimpacts/publications/ en/Indoorsmoke.pdf

5. Gupta D, Agarwal R, Aggarwal AN, Maturu VN, Dhooria S, Prasad KT, et al. Guidelines for diagnosis and management of chronic obstructive pulmonary disease: joint ICS/NCCP (I) recommendations. Lung India. 2013; 30(3):228. 
6. Bruce N, Perez-Padilla R, Albalak R. Indoor air pollution in developing countries: a major environmental and public health challenge. Bull World Health Organ. 2000;78(9):1078-92.

7. Forum of International Respiratory Societies. The Global Impact of Respiratory Disease [Internet]. European Respiratory Society; 2017. Report No.: 2nd edition. Available from: https://www.who.int/gard/publications/ The_Global_Impact_of_Respiratory_Disease.pdf

8. National Institute of Statistics C. 2018 demographic and health survey. Cameroon: National Institute of Statistics; 2019. Available from: https:// dhsprogram.com/pubs/pdf/SR266/SR266.pdf

9. Tazinya AA, Halle-Ekane GE, Mbuagbaw LT, Abanda M, Atashili J, Obama MT. Risk factors for acute respiratory infections in children under five years attending the Bamenda Regional Hospital in Cameroon. BMC Pulm Med. 2018 16;18. Available from: https://www.ncbi.nlm.nih.gov/pmc/articles/PMC5 771025/ [cited 2020 Sep 16]

10. Santus P, Russo A, Madonini E, Allegra L, Blasi F, Centanni S, et al. How air pollution influences clinical management of respiratory diseases. A casecrossover study in Milan. Respir Res. 2012;13(1):95.

11. World Health Organisation. WORLD HEALTH STATISTICS 2018 [Internet]. WHO; 2018. Available from: https://apps.who.int/iris/bitstream/handle/1 0665/272596/9789241565585-eng.pdf?ua=1

12. Cameroon M of PH. HEALTH SECTOR STRATEGY 2016-2027 [Internet]. 2016. Available from: https://www.minsante.cm/site/sites/default/files/HSS_ english_0.pdf

13. World Health Organisation. Burning Opportunity: Clean Household Energy for Health, Sustainable Development, and Wellbeing of Women and Children; [Internet]. 2016. Available from: https://www.who.int/airpollution/ publications/burning-opportunities/en/

14. World Health Organisaton. WHO guidelines for Indoor Air Quality Guidelines: Household Fuel Combustion [Internet]. 2014. Available from: https://www.who.int/airpollution/guidelines/household-fuel-combustion/ IAQ_HHFC_guidelines.pdf

15. Lynch DA, Austin JHM, Hogg JC, Grenier PA, Kauczor H-U, Bankier AA, et al. CT-definable subtypes of chronic obstructive pulmonary disease: a statement of the Fleischner society. Radiology. 2015;277(1):192-205.

16. Pope D, Bruce N, Higgerson J, Hyseni L, Ronzi S, Stanistreet D, et al. Household determinants of Liquified petroleum gas (LPG) as a cooking fuel in south West Cameroon. Ecohealth. 2018;15(4):729-43.

17. Nlom JH, Karimov AA. Modeling fuel choice among households in northern Cameroon. Sustainability. 2015;7(8):9989-99.

18. Pope D, Bruce N, Higgerson J, Hyseni L, Stanistreet D, MBatchou B, et al. Household determinants of Liquified petroleum gas (LPG) as a cooking fuel in SW Cameroon. EcoHealth. 2018;15(4):729-43.

19. Pye A, Ronzi S, Mbatchou Ngahane BH, Puzzolo E, Ashu AH, Pope D. Drivers of the adoption and exclusive use of clean fuel for cooking in sub-Saharan Africa: Learnings and policy considerations from Cameroon. Int J Environ Res Public Health. 2020;17(16):5874.

20. Njong AM, Johannes TA. An analysis of domestic cooking energy choices in Cameroon. Eur J Soc Sci. 2011:20:336-47.

21. Mbatchou Ngahane BH, Afane Ze E, Chebu C, Mapoure NY, Temfack E, Nganda $\mathrm{M}$, et al. Effects of cooking fuel smoke on respiratory symptoms and lung function in semi-rural women in Cameroon. Int J Occup Environ Health. 2015;21(1):61-5.

22. Ranabhat CL, Kim C-B, Kim C-S, Jha N, Deepak KC, Connel FA. Consequence of Indoor Air Pollution in Rural Area of Nepal: A Simplified Measurement Approach. Front Public Health [Internet]. 2015 [cited 2019 Jul 6];3. Available from: https://www.frontiersin.org/articles/10.3389/fpubh.2015.00005/full

23. Lu C-Y, Kang S-Y, Liu S-H, Mai C-W, Tseng C-H. Controlling Indoor Air Pollution from Moxibustion. Int J Environ Res Public Health. 2016;13:612.

24. Behera D, Balamugesh T. Indoor air pollution as a risk factor for lung cancer in women. J Assoc Physicians India. 2005 Mar;53:190-2.

25. Cameroon - ministerial outcome.pdf [Internet]. [cited 2019 Jul 21]. Available from: https://wedocs.unep.org/bitstream/handle/20.500.11822/21238/ Cameroon\%20-\%20ministerial\%20outcome.pdf?sequence=3\&isAllowed=y

26. National Institute of Statistics 2014 Demographic and health survey [internet]. National Institute of Statistics; 2015. Available from: https://micssurveys-prod.s3.amazonaws.com/MICS5/West\%20and\%20Central\%20Africa/ Cameroon/2014/Final/Cameroon\%202014\%20MICS_French.pdf

\section{Publisher's Note}

Springer Nature remains neutral with regard to jurisdictional claims in published maps and institutional affiliations.
Ready to submit your research? Choose BMC and benefit from:

- fast, convenient online submission

- thorough peer review by experienced researchers in your field

- rapid publication on acceptance

- support for research data, including large and complex data types

- gold Open Access which fosters wider collaboration and increased citations

- maximum visibility for your research: over $100 \mathrm{M}$ website views per year

At BMC, research is always in progress.

Learn more biomedcentral.com/submissions 